\title{
A novel mutation in the PAX8 promoter region causes permanent congenital hypothyroidism in a patient with Down's Syndrome
}

\author{
Pia Hermanns ${ }^{*}$, Sunia Khadouma ${ }^{1}$, Scott Shepherd ${ }^{2}$, Mohamed Mansor $^{3}$, John Schulga ${ }^{3}$, J Jones ${ }^{2}$, M Donaldson $^{2}$, \\ Joachim Pohlenz ${ }^{1}$
}

From 50th Workshop for Pediatric Research

Gottingen, Germany. 20-21 March 2014

Thyroid dysfunction is common in newborn infants with Down's syndrome (DS) but defects in organogenesis have not been described. A female infant was diagnosed to have trisomy 21, atrio-ventricular septal defect and patent ductus. Newborn screening showed capillary TSH $43.8 \mathrm{mU} / \mathrm{L}$ (day 5), venous TSH $>150 \mathrm{mU} / \mathrm{l}$ and free T4 $15.1 \mathrm{pmol} / \mathrm{L}$ (day 12). Thyroid ultrasound showed a small gland with heterogenous echotexture and cystic changes. Scintigraphy showed normal uptake into an eutopic gland. The infant was treated with thyroxine and underwent cardiac repair at 69 days. Sequencing analysis of candidate genes involved in thyroid development revealed a new heterozygous mutation close to the transcription initiation site of the $P A X 8$ gene. Electromobility shift assay (EMSA) studies exhibited that the sequence at this position is not involved in specific protein binding. However, the mutant $P A X 8$ promoter showed a significantly reduced transcriptional activation of a luciferase reporter gene in vitro tested in HEK, PCCL3 as well as in HeLa cells indicating that the mutation is very likely to lead to a reduced $P A X 8$ gene expression. Further study in infants with DS and TSH elevation are indicated to investigate whether or not there is a true association between DS and PAX8 mutations.

\footnotetext{
Authors' details

'Department of Pediatrics, Johannes Gutenberg University Medical School, Mainz, Germany. ${ }^{2}$ Child Health Unit, School of Medicine, Royal Hospital for Sick Children, Glasgow G3 8SJ, UK. ${ }^{3}$ Department of Paediatrics, Forth Valley Royal Hospital, Larbert FK5 4WR, UK.
}

Published: 11 September 2014

'Department of Pediatrics, Johannes Gutenberg University Medical School, Mainz, Germany

Full list of author information is available at the end of the article
doi:10.1186/2194-7791-1-S1-A24

Cite this article as: Hermanns et al: A novel mutation in the PAX8 promoter region causes permanent congenital hypothyroidism in a patient with Down's Syndrome. Molecular and Cellular Pediatrics 20141 (Suppl 1):A24.

\section{SpringerOpen ${ }^{\circ}$}

C 2014 Hermanns et al; licensee Springer This is an Open Access article distributed under the terms of the Creative Commons Attribution License (http://creativecommons.org/licenses/by/2.0), which permits unrestricted use, distribution, and reproduction in any medium, provided the original work is properly cited.
Submit your manuscript to a SpringerOpen ${ }^{\circ}$ journal and benefit from:

- Convenient online submission

- Rigorous peer review

- Immediate publication on acceptance

- Open access: articles freely available online

- High visibility within the field

- Retaining the copyright to your article

Submit your next manuscript at $\boldsymbol{~ s p r i n g e r o p e n . c o m ~}$ 